\title{
Homocytotropic antibodies (IgE) to Neisseria gonorrhoeae in the rat and a cross-reactivity of heterologous gonococcal strains
}

\author{
H. M. VIJAY, G. LAVERGNE, F. E. ASHTON, A. RYAN, AND B. B. DIENA \\ From the Health Protection Branch, Health and Welfare, Canada, Ottawa, Ontario
}

SUMMARY Outbred Wistar rats were immunised with a single intraperitoneal injection of a mixture of $30 \mathrm{mg}$ of $\mathrm{Al}(\mathrm{OH})_{3}$ and $100 \mu \mathrm{g}$ of gonococcal zeolite antigen (ZA). Ten days after immunisation, ZA prepared from $T_{1}$ and $T_{4}$ colonies of Neisseria gonorrhoeae strain GC6 (GC6- $T_{1} Z A$ and GC6- $T_{4}$ $\mathrm{ZA}$ ) were able to elicit a reaginic (IgE) response which declined to low levels by 35 days. There was a significant amount of histamine release from the mast cells of actively-sensitised rats on challenge with a specific gonococcal antigen. The antisera heated at a temperature of $56^{\circ} \mathrm{C}$ for four hours failed to elicit a passive cutaneous anaphylaxis (PCA) reaction, indicating a lack of IgGa antibody. In addition antisera to GC6- $T_{1}$ ZA gave a positive PCA reaction with GC6-T ${ }_{4} Z A$ and $\mathrm{ZA}$ prepared from $\mathrm{T}_{1}$ colonies of six heterologous gonococcal strains suggesting that these strains of $N$. gonorrhoeae share common antigenic determinants.

\section{Introduction}

Gonorrhoea remains one of the world's most commonly reported communicable diseases (Kiraly and Causse, 1975). A factor responsible for the current epidemic is the difficulty in detecting asymptomatic carriers of gonorrhoea (Pariser and Marino, 1970; Pariser, 1972). Thus, a reliable serodiagnostic test to detect asymptomatic carriers of gonorrhoea would greatly help to control the disease.

Several serological tests-such as, complement fixation, flocculation, microprecipitin, and passive haemagglutination-have been used with limited success for the serodiagnosis of gonorrhoea (Kellogg and Balows, 1976). Also, some studies have been carried out on the response of specific immunoglobulins $\operatorname{IgA}, \operatorname{IgG}$, IgM, and secretory $\operatorname{IgA}$ to gonococcal infection employing whole cells or purified pili as antigens (Cohen et al., 1969; Buchanan et al., 1973; O'Reilly et al., 1976).

Of particular interest is a report that the mean serum IgE level was higher in a group of patients with gonorrhoea compared with a group of normal individuals (Green et al., 1976). However, little is known about reaginic (IgE) antibody response to antigenic stimulus of Neisseria gonorrhoeae. It has been shown that IgE antibodies are produced in

Address for reprints: Dr B. B. Diena, Laboratory Centre for Disease Control, Health Protection Branch, Tunney's Pasture, Ottawa, Canada K1A OL2

Received for publication 5 November 1976 response to infections in rats by parasites (PerrudetBadoux et al., 1976). Also, IgE antibodies are formed in mice immunised with water soluble antigens isolated from certain Gram-negative bacteria (Danneman and Michael, 1976).

The current study was designed to develop an animal model for the production of IgE antibodies to gonococcal antigens. This model would be useful for the monitoring of purified gonococcal antigens which are capable of stimulating IgE antibody response. Such antigens might be employed for the serodiagnosis of gonorrhoea based on IgE antibody formation to infection with $N$. gonorrhoeae in humans.

\section{Material and methods}

\section{BACTERIA}

The source of $N$. gonorrhoeae strains GC6, 188, IN31, and G9 has been described previously (Perry et al., 1975). Other strains (LCDC No. GC-15, 74123 and 74002) were obtained from the Regional Public Health Laboratory, Bell's Corner, Ontario. The strains were maintained as colony type 1 $\left(T_{1}\right)$ or $4\left(T_{4}\right)$ by daily passage on GC medium (Kellogg et al., 1963).

PREPARATION OF ZEOLITE ANTIGENS

One gram (wet weight) of viable gonococci was placed in a mortar in an ice-bath and $2 \mathrm{~g}$ of zeolite (type $4 \mathrm{~A}$, received as a gift from Union carbide, 
Linde Division, New York, NY) was added slowly while grinding with a pestle for three minutes. Grinding was continued for another three minutes while $100 \mathrm{ml}$ of cold distilled water was added to the mortar. The suspension was centrifuged at $3000 \mathrm{~g}$ to remove intact gonococci and zeolite particles. The supernatant was centrifuged at $40000 \mathrm{~g}$ for one hour at a temperature of $4^{\circ} \mathrm{C}$ to remove particulate material. The supernatant was designated as zeolite antigen (ZA).

\section{PROTEIN CONCENTRATIONS}

The content of protein in each preparation was determined by the method of Lowry et al. (1951). Bovine albumin (Fraction V from bovine plasma) obtained from Armour Pharmaceutical Company, Chicago, Illinois was used as a standard.

\section{IMMUNISATION OF RATS}

Two groups, each consisting of 10 , male outbred Wistar rats weighing 225-250 g (Woodlyn Farms, Guelph, Ontario) were immunised with a single intraperitoneal injection of $1.0 \mathrm{ml}$ of mixture containing $100 \mu \mathrm{g}$ of ZA prepared from $N$. gonorrhoeae strain GC6, colony type 1 or $4\left(\mathrm{GC}-\mathrm{T}_{1} \mathrm{ZA}\right.$ or GC6-T $\left.{ }_{4} \mathrm{ZA}\right)$ precipitated with $30 \mathrm{mg}$ of aluminum hydroxide gel $\left(\mathrm{Al}(\mathrm{OH})_{3}\right)$. The animals were given halothane anaesthesia and bled by cardiac puncture at 10,22 , and 35 days after immunisation. Not more than $3 \mathrm{ml}$ were withdrawn if the rats were to be kept. After allowing the blood to clot at $25^{\circ} \mathrm{C}$ for between one and two hours followed by standing overnight at $4^{\circ} \mathrm{C}$, the serum was separated by centrifugation and stored at $-70^{\circ} \mathrm{C}$ until used in passive cutaneous anaphylaxis (PCA) reactions.

\section{ANTIBODY DETERMINATIONS}

The level of circulating reagins (IgE) was estimated by PCA test (Ovary, 1964) with a sensitisation period of 48 hours. Thus $0 \cdot 1 \mathrm{ml}$ quantities of saline dilutions of test serum were injected intradermally into the skin of recipient rats (outbred Wistar) and each injection was duplicated on different animals. The animals were injected intravenously 48 hours later with either $0.6 \mathrm{ml}(1.6 \mathrm{mg} / \mathrm{ml}$ protein) of GC6-T $_{1}$ ZA or $0.75 \mathrm{ml}(1.35 \mathrm{mg} / \mathrm{ml}$ protein $)$ of GC-6T ${ }_{4}$ ZA mixed with $0.5 \mathrm{ml}$ of $2 \%$ Evans's blue dye. The skin reactions were examined after 30 minutes. The antibody titres were determined in triplicate and are expressed as the reciprocal of the highest dilution giving a diameter greater than $5 \mathrm{~mm}$ in the blueing reaction.

An attempt was also made to detect heat-stable (IgGa) homocytotropic antibody by performing the four-hour PCA tests with sera heated at $56^{\circ} \mathrm{C}$ for four hours.
HISTAMINE RELEASE FROM MAST CELLS OF ACTIVELY SENSITISED RATS

Two rats from each group were selected randomly on days 10,22 , and 35 after immunisation. The cells were harvested from the rats as reported earlier (Vijayanagar et al., 1974). A modified technique of Evans and Thomson (1972) was used to determine the ability of the mast cells from actively sensitised rats to release histamine on challenge with homologous zeolite antigens either GC6-T ${ }_{1} \mathrm{ZA}$ or GC6-T ${ }_{4} \mathrm{ZA}$. The challenging dose of the antigens used in histamine release ranged from 1-200 $\mu \mathrm{g}$.

\section{Results and discussion}

REAGINIC ANTIBODY RESPONSE

Table 1 shows the mean homocytotropic antibody titre in the sera of rats immunised with gonococcal antigens. It is evident that reaginic (IgE) antibodies of maximum response were present in the sera of the rats 10 days after immunisation with GC6-T ${ }_{1} \mathrm{ZA}$ and GC6-T 4 ZA. These reagins had declined by day 22 (maximum PCA titre, 16) and were hardly detectable on day 35 (PCA titre, 0-1). Antiserum to GC6-T 1 ZA gave a significant PCA titre when challenged with GC6-T ${ }_{4} \mathrm{ZA}$ and vice versa.

Table 1 Mean* homocytotropic (IgE) antibody titres in rats immunised with gonococcal (zeolite) antigens

\begin{tabular}{|c|c|c|c|c|c|c|c|c|c|}
\hline \multirow{4}{*}{$\begin{array}{l}\text { Immunising } \\
\text { antigen }\end{array}$} & \multirow{2}{*}{\multicolumn{3}{|c|}{$\begin{array}{l}\text { No. of rats } \\
\text { positive } †\end{array}$}} & \multicolumn{6}{|c|}{$\begin{array}{l}\text { Reciprocal PCA titres on } \\
\text { challenge with }\end{array}$} \\
\hline & & & & \multicolumn{3}{|c|}{$G C 6-T_{1} Z A$} & \multicolumn{3}{|c|}{$G C 6-T_{4} Z A$} \\
\hline & \multicolumn{9}{|c|}{ Days after immunisation } \\
\hline & 10 & 22 & 35 & 10 & 22 & 35 & 10 & 22 & 35 \\
\hline $\begin{array}{ll}\text { GC6-T }_{1} & \mathrm{ZA} \\
\text { GC6-T }_{4} & \mathrm{ZA}\end{array}$ & $\begin{array}{l}10 / 10 \\
10 / 10\end{array}$ & $\begin{array}{l}8 / 8 \\
6 / 8\end{array}$ & $\begin{array}{l}1 / 6 \\
0 / 6\end{array}$ & $\begin{array}{l}64 \\
32\end{array}$ & $\begin{array}{l}4 \\
8\end{array}$ & $\begin{array}{l}2 \\
0\end{array}$ & $\begin{array}{l}128 \\
128\end{array}$ & $\begin{array}{l}16 \\
16\end{array}$ & $\begin{array}{l}1 \\
0\end{array}$ \\
\hline
\end{tabular}

* In each group, positive sera were pooled.

†Undiluted sera of the rats were tested by PCA reaction using GC6-T ${ }_{1} \mathrm{ZA}$ as a challenging antigen.

HISTAMINE RELEASE FROM MAST CELLS OF ACTIVELY SENSITISED RATS

Mast cells from actively sensitised rats were challenged with homologous $\mathrm{ZA}$ to determine if there was cellbound IgE specific to the gonococcal zeolite antigens. Table 2 shows that 10 days after immunisation, there was $60-84 \%$ histamine release which declined to $23-47 \%$ after 22 days. By day 35 there was still an appreciable amount of histamine release from mast cells of rats immunised with GC6-T ${ }_{4} \mathrm{ZA}$. However, there was no histamine release in rats immunised with GC6-T, ZA. Since the rats were selected randomly for histamine release and the PCA titres were done on pooled antisera, it was not 
Table 2 Per cent of histamine release from actively sensitised rat peritoneal mast cells on challenge with zeolite antigens prepared from $\mathbf{N}$. gonorrhoeae strain GC6

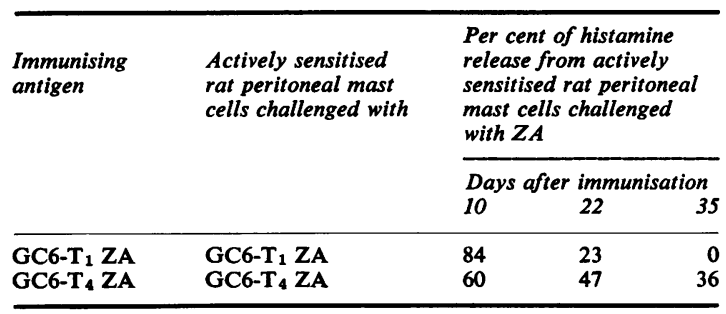

possible to correlate the amount of histamine release with the corresponding PCA titre. However, it is noteworthy that on day 35 after immunisation, although no PCA reaction could be detected in the sera of animals immunised with GC6-T 4 ZA (Table 1), there was a considerable amount $(36 \%)$ of histamine release from the mast cells of these rats on challenge with GC6-T,$Z A$. These results suggest that cellbound IgE does not always parallel the amount of circulating antigen specific IgE antibodies. These observations are in agreement with those of Yamamoto et al. (1974).

In addition, it is important to point out that before a challenge with the specific gonococcal antigen, a large number of actively sensitised mast cells were degranulated. If this is true, the leucocytes of patients infected with gonorrhoea should be studied.

CROSS-REACTIVITY OF GC6-T, ZA

ANTISERA WITH HETEROLOGOUS

GONOCOCCAL STRAINS

In order to examine the cross-reactivity of GC6-T ZA with zeolite antigens prepared from other strains of $N$. gonorrhoeae, antisera obtained from rats 10 days after immunisation, were challenged with $\mathrm{ZA}$ prepared from $T_{1}$ colonies of six heterologous gonococcal strains. The results in Table 3 indicate that GC6 $T_{1}$ ZA antiserum contained IgE antibody which cross-reacted with $\mathrm{ZA}$ from all six hetero-

Table 3 Cross-reactivity of GC6-T $T_{1}$ ZA antiserum with $Z A$ obtained from $T_{1}$ colonies of six different strains of N. gonorrhoeae

\begin{tabular}{lc}
\hline Challenging zeolite antigen & Reciprocal PCA titre* \\
\hline GC6 & 64 \\
G9 & 64 \\
IN31 & 128 \\
74123 & 64 \\
188 & 64 \\
GC15 & 128 \\
74002 & 128 \\
\hline
\end{tabular}

*Determined with sera obtained from rats 10 days after immunisation with GC6-T, ZA. logous strains of $N$. gonorrhoeae. The antisera heated at $56^{\circ} \mathrm{C}$ for four hours failed to elicit a four-hour PCA reaction, indicating a lack of IgGa antibody. These results suggest that these strains have common antigenic determinants and support previous studies which indicate that one or more common proteins to several gonococcal strains are present in the ZA (Wallace et al., 1977). Studies are currently under way to isolate the specific antigen(s) which are responsible for the production of $\mathrm{IgE}$ in rats and are common among the various gonococcal strains. Such antigens may be useful in the development of a serodiagnostic test for gonorrhoea based on the detection of IgE antibodies produced in response to gonococcal infection.

\section{References}

Buchanan, T. M., Swanson, J., Holmes, K. K., Kraus, S. J., and Gotschlich, E. C. (1973). Quantitative determination of antibody to gonococcal pili. Changes in antibody levels with gonococcal infection. Journal of Clinical Investigation, 52, 2896-2909.

Cohen, I. R., Kellogg, D. S., and Norins, L. C. (1969). Serum antibody response in experimental human gonorrhoea, British Journal of Venereal Diseases, 45, 325-327.

Danneman, P. J., and Michael, J. G. (1976). Reaginic antibody production to protein antigens of Escherichia coli and Pseudomonas aeruginosa by mice. Infection and Immunity, 14, 694-702.

Evans, D. P., and Thomson, D. S. (1972). Histamine release from rat mast cells passively sensitised with homocytotropic (IgE) antibody. International Archives of Allergy and Applied Immunology, 43, 217-231.

Green, R. L., Scales, R. W., and Kraus, S. J. (1976). Increased serum immunoglobulin $\mathrm{E}$ concentrations in venereal diseases. British Journal of Venereal Diseases, 52, 257-260.

Kellogg, D. S., and Balows, A. (1976). Manual of Clinical Immunology, p.280. Edited by N. R. Rose and H. Friedman. American Society for Microbiology: Washington D.C.

Kellogg, D. S., Peacock, W. L., Deacon, W. E., Brown, L., and Pirkle, C. I. (1963). Neisseria gonorrhoeae. I. Virulence genetically linked to clonal variation. Journal of Bacteriology, 85, 1274-1279.

Kiraly, K., and Causse, G. (1975). International Symposium on Gonorrhea, p.14. Edited by B. B. Diena. Health and Welfare Canada: Ottawa.

Lowry, O. H., Rosebrough, N. J., Farr, A. L., and Randall, R. J. (1951). Protein measurement with the Folin phenol reagent. Journal of Biological Chemistry, 193, 265-275.

O'Reilly, R. J., Lee, L., and Welch, B. G. (1976). Secretory IgA antibody responses to Neisseria gonorrhoeae in the genital secretions of infected females. Journal of Infectious Diseases, 133, 113-125.

Ovary, Z. (1964). Immunological Methods, p.259. Edited by J. F. Ackroyd. Blackwell: Oxford.

Pariser, H. (1972). Asymptomatic gonorrhea. Medical Clinics of North America, 56, 1127-1132.

Pariser, H., and Marino, A. F. (1970). Gonorrhea-frequently unrecognised reservoirs. Southern Medical Journal, 63, 198-201.

Perrudet-Badoux, A., Binaghi, R. A., and Boussac-Aron, Y. (1976) Production of different classes of immunoglobulins in rats infested with Trichinella spiralis, Immunochemistry 13, 443-446.

Perry, M. B., Daoust, V., Diena, B. B., Ashton, F. E., and Wallace, R. (1975). The lipopolysaccharides of Neisseria gonorrhoeae colony types 1 and 4. Canadian Journal of Biochemistry, 53, 623-629.

Vijayanagar, H. M., Attallah, N. A., David, M. F., and Sehon, A. H. (1974). Detection of human reagins with rat peritoneal mast cells by histamine release. International Archives of Allergy and Applied Immunology, 46, 375-392.

Wallace, R., Ashton, F. E., Ryan, A., Diena, B. B., and Vijay, H. M. (1977). Preparation of gonococcal antigens by zeolite disruption. Canadian Journal of Microbiology, 23, 122-124.

Yamamoto, S., Seo, K., Fujiwara, Y., Maeda, M., and Yamura, T. (1974). Correlation between in vitro anaphylactic histamine release from tissues and reagin titer in rat. International Archives of Allergy and Applied Immunology, 47, 329-338. 